\title{
Responses to flooding of plant water relations and leaf gas exchange in tropical tolerant trees of a black-water wetland
}

\author{
A. Herrera* \\ Centro de Botánica Tropical, Instituto de Biología Experimental, Universidad Central de Venezuela, Caracas, Venezuela
}

\section{Edited by:}

Rens Voesenek, Utrecht University,

Netherlands

\section{Reviewed by:}

Uener Kolukisaoglu, University of

Tuebingen, Germany

Vasileios Fotopoulos, Cyprus

University of Technology, Cyprus

*Correspondence:

A. Herrera, Centro de Botánica

Tropical, Instituto de Biología

Experimental, Universidad Central

de Venezuela, Calle Suapure,

Colinas de Bello Monte, Caracas

1050, Venezuela.

e-mail:ana.herrera@ciens.ucv.ve
This review summarizes the research on physiological responses to flooding of trees in the seasonal black-water wetland of the Mapire River in Venezuela. Inter-annual variability was found during 8 years of sampling, in spite of which a general picture emerged of increased stomatal conductance $\left(g_{s}\right)$ and photosynthetic rate $\left(P_{N}\right)$ during the flooded period to values as high as or higher than in plants in drained wet soil. Models explaining the initial inhibitory responses and the acclimation to flooding are proposed. In the inhibitory phase of flooding, hypoxia generated by flooding causes a decrease in root water absorption and stomatal closure. An increase with flooding in xylem water potential $(\psi)$ suggests that flooding does not cause water deficit. The $P_{N}$ decreases due to changes in relative stomatal and non-stomatal limitations to photosynthesis; an increase in the latter is due to reduced chlorophyll and total soluble protein content. Total non-structural carbohydrates (TNC) accumulate in leaves but their content begins to decrease during the acclimatized phase at full flooding, coinciding with the resumption of high $g_{s}$ and $P_{N}$. The reversal of the diminution in $\mathrm{g}_{\mathrm{s}}$ is associated, in some but not all species, to the growth of adventitious roots. The occurrence of morpho-anatomical and biochemical adaptations which improve oxygen supply would cause the acclimation, including increased water absorption by the roots, increased rubisco and chlorophyll contents and ultimately increased $\mathrm{P}_{\mathrm{N}}$. Therefore, trees would perform as if flooding did not signify a stress to their physiology.

Keywords: flooding, photosynthesis, sap flux, stomatal conductance, tolerance

\section{INTRODUCTION}

Flooding brings about a number of changes to the soil environment, including among others reduction in oxygen concentration (Kozlowski, 1984), generation of reduced ions and, additionally, diminution of irradiance incident on leaves. Flood tolerance depends on the depth of the water column, the duration of the flooded period and specific plant traits (Colmer and Voesenek, 2009). Partial or total oxygen deficiency in the roots of higher plants causes morphological, anatomical and biochemical changes, and anoxia-tolerance seems to be strictly organ-specific (Drew, 1997); such changes allow plants of tolerant species to revert to normoxic condition as flooding progresses (Pezeshki, 1993).

A large number of articles have been published on physiological responses to waterlogging/flooding in temperate tolerant plants, both herbs and trees, as well as the tropical herb, rice, but less is known about the physiological, let alone biochemical or molecular, responses of tropical species, especially trees. I here review the existing literature on tropical tolerant trees, while comparing these with temperate tolerant and intolerant species.

Flood tolerance varies greatly with, among other factors, plant species and age, and time and duration of flooding (Kozlowski, 1997). A reduction in $g_{s}$ and $P_{N}$ are the earliest response to flooding observed in intolerant as well as tolerant species (Pezeshki, 1993; Batzli and Dawson, 1997; Fernández et al., 1999). In tropical flood-tolerant trees, reductions in $\mathrm{P}_{\mathrm{N}}$ and $\mathrm{g}_{\mathrm{s}}$ are reverted later on as flooding progresses (Fernández et al., 1999; Rengifo et al., 2005), as shown previously in temperate flood-tolerant trees (Pezeshki, 1993).

One of the main reasons why hypoxia due to flooding reduces $\mathrm{g}_{\mathrm{s}}$ is decreased root water absorption (Kozlowski, 1984; Tournaire-Roux et al., 2003) through reductions in root hydraulic conductivity (Aroca et al., 2011). The decrease in $\mathrm{P}_{\mathrm{N}}$ observed in flood-tolerant herbaceous and tree species is apparently governed not only by stomatal but also by non-stomatal (mesophyll) factors (Pezeshki, 1987, 1993).

In riparian Panamazonian forests, trees can suffer regular, long-lasting and deep flooding, when white-water rivers such as the Orinoco or black-water rivers such as the Rio Negro overflow, thus creating floodplain ecosystems called in the first case várzea and in the second, igapó (Prance, 1979). These ecosystems differ, among other traits, in quality of the waters; várzeas have nutrientrich, turbid and higher $\mathrm{pH}$ waters, whereas in the igapós waters are very nutrient-poor, transparent and acidic. These characteristics are bound to affect plant physiology and growth differently. Amazonian wetlands cover over $1,000,000 \mathrm{~km}^{2}$ (Melack et al., 2004), more than three times the area of the British Isles; therefore, knowing how tropical plants cope with flooding becomes of global importance.

Flood tolerance has been extensively examined in herbaceous or small floating and submerged angiosperms (revised by Colmer and Voesenek, 2009). Here, I will be dealing with large trees, which will surely make a difference because of resistances 
encountered by long-distance transport of $\mathrm{O}_{2}$ and the slow diffusion of this gas in water. In tropical wetlands, the water-column may be as high as $10-15 \mathrm{~m}$ and the flood period last up to 7 months (Vegas-Vilarrúbia and Herrera, 1993a; Parolin et al., 2006).

This review summarizes the results of research on physiological responses to flooding of trees in the seasonal igapó of the Mapire River. This igapó is formed when the blackwater Mapire River, a northern tributary of the Orinoco, increases its flow due to rainfall and is additionally dammed by the Orinoco. Four broad phases can be defined in the flood cycle (Figure 1A): drainage (D, December-March), risingwaters (RW, April-May), full flood (FF, June-August), and falling-waters (FW, September-November). The igapó lake covers trees at various heights depending on tree size and position along a gradient from the savanna to the river channel (Figure 1B). The species that have been examined along this gradient are Acosmium nitens (Papilionaceae), Campsiandra laurifolia (Mimosaceae), Eschweilera tenuifolia (Lecythidaceae), Pouteria orinocoensis (Sapotaceae), Symmeria paniculata (Polygonaceae), and Psidium ovatifolium (Myrtaceae). The aspect of this ecosystem at drainage and full flood is shown in Figure 2. All species in the Mapire igapó are evergreen. Several, such as C. laurifolia, S. paniculata, and $P$. ovatifolium, retain leaves underwater.

Similar plant responses have been repeatedly observed during the various stages of the flood cycle. I will focus this review on results obtained in the field by Fernández et al. (1999), Rengifo et al. (2005), and Herrera et al. (2008a,b). In spite of inter-annual variability in gas exchange found during eight non-consecutive years of sampling, a general picture emerged of increased $g_{s}$ and $\mathrm{P}_{\mathrm{N}}$ during the flooded period to values as high as or higher than in plants in drained yet wet soil (Figure 3). The inter-annual variability may be due, among other factors, to differences in the exact timing of the flood phase, leaf developmental stage, rainfall, air temperature, and relative humidity. For example, measurements made in 1998 (Rengifo et al., 2005) were most certainly affected by the fact that this, as opposed to the other years of sampling, was a strong El Niño year. Based on these results and the literature, model are proposed (Figure 4) explaining physiological responses to the inhibitory and the acclimatized phases of flooding in species growing exclusively in this ecosystem.
A

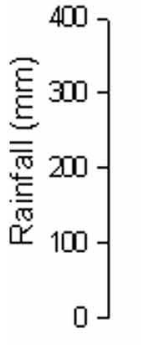

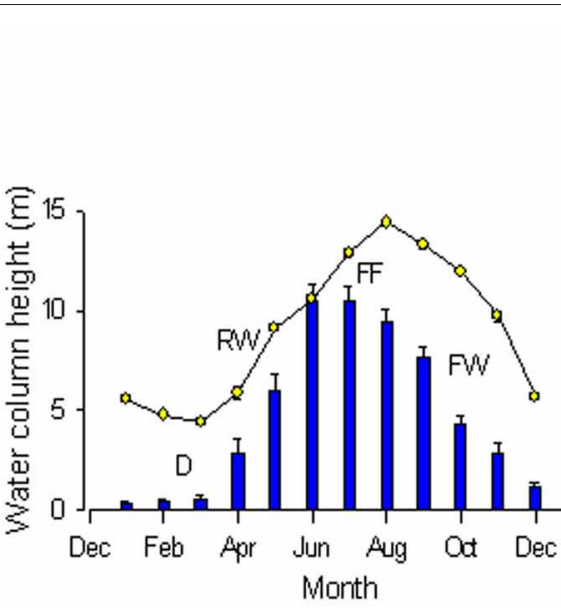

B

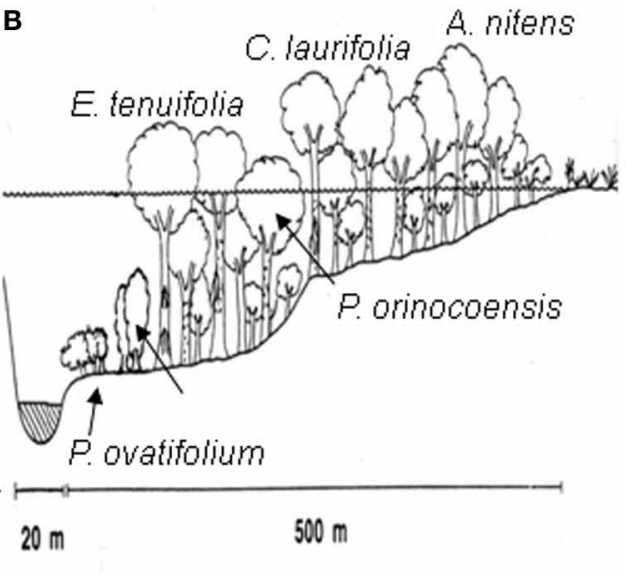

FIGURE 1 | (A) Changes over the year in rainfall (bars) and water column height (circles) of the Mapire River relative to the Orinoco. Values are mean $\pm S E$ ( $n=4$ years). Stages of the flooding cycle are indicated as drainage (D), rising-waters (RW), full flooding (FF), and falling-waters
(FW). (B) Schematic view of the vegetation and water level along a gradient from the Mapire bed to the savanna. Approximate location of species indicated. Modified from Fernández et al. (1999) and Herrera et al. (2008b).
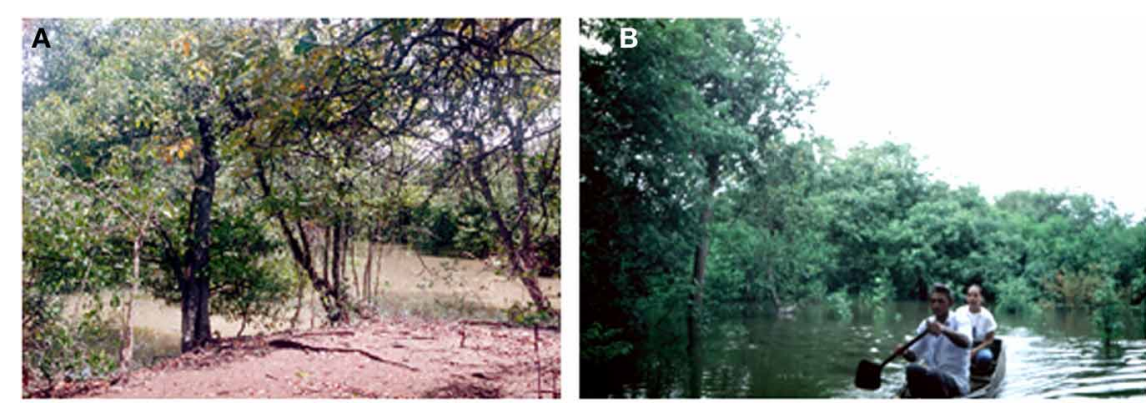

FIGURE 2 | The Mapire igapó forest during (A) drainage and (B) under full flood. 


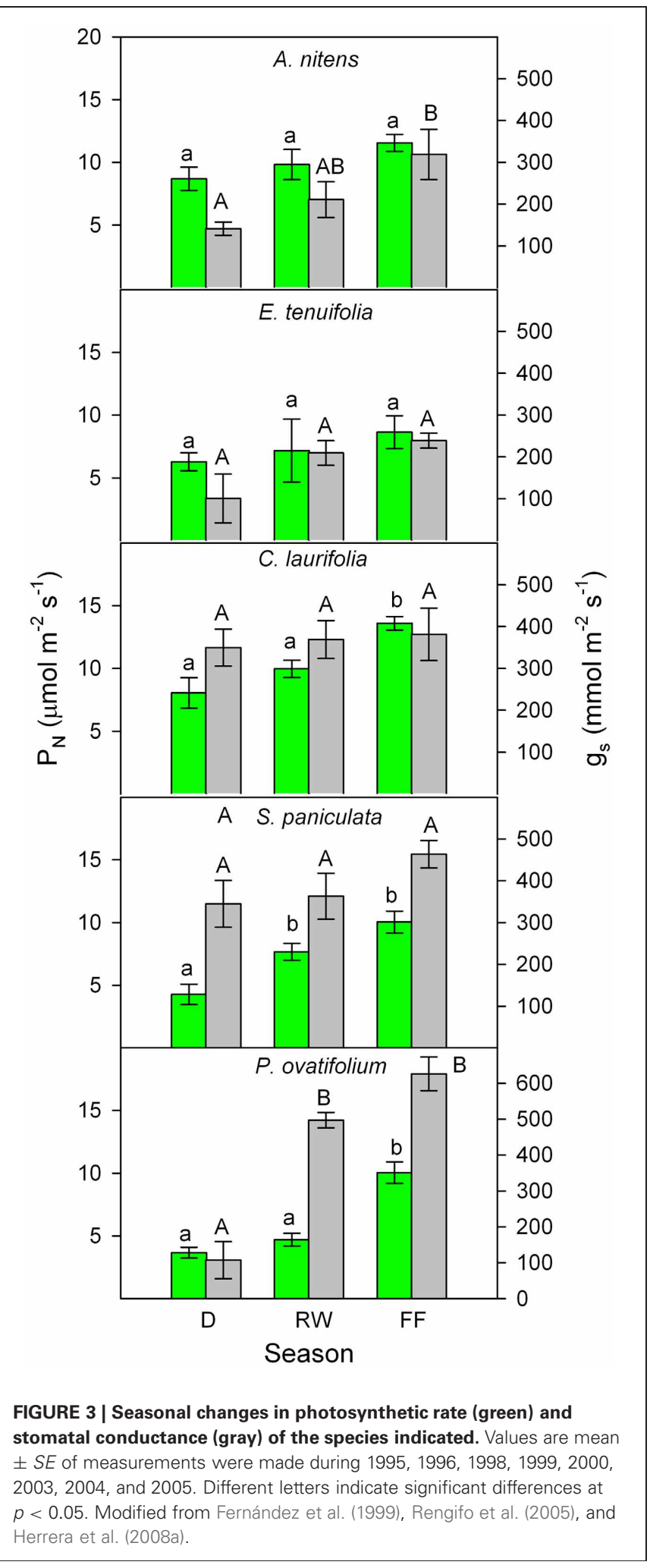

I will present evidence in favor or against the proposed models. Results on water status, leaf gas exchange and Total non-structural carbohydrates (TNC) are shown in Table $\mathbf{1}$ and will be discussed where pertinent. The following issues will be examined: (1) Just how low does oxygen concentration become and how does it affect root water absorption and water status? (2) Are reductions in $\mathrm{g}_{\mathrm{s}}$ and $\mathrm{P}_{\mathrm{N}}$ under flooding reversible? (3) Does flooding cause photoinhibition? (4) Are changes in $\mathrm{P}_{\mathrm{N}}$ under flooding caused by changes in stomatal and non-stomatal limitations? (5) How does leaf carbohydrate balance change during flooding?

The significance of under-water photosynthesis for wholeplant $\mathrm{C}$ balance and the possible changes under flooding in leaf anatomy will be examined, and some eco-physiological and ecological considerations made.

\section{MODELS OF PHYSIOLOGICAL RESPONSES TO THE INHIBITORY AND THE ACCLIMATIZED PHASES OF FLOODING}

Flooding at the inhibitory phase (RW) causes hypoxia, probably not anoxia. Hypoxia generates changes in hormone balance that cause stomatal closure and a decrease in absorption of water by roots, which may also promote stomatal closure. This brings about a decrease in intercellular $\mathrm{CO}_{2}$ concentration, $\mathrm{C}_{\mathrm{i}}$ and $\mathrm{P}_{\mathrm{N}}$. The decrease in $\mathrm{g}_{\mathrm{s}}$ and $\mathrm{P}_{\mathrm{N}}$ under high radiation and air evaporative demand could induce chronic photoinhibition. The decrease with flooding in soil $\mathrm{N}$ and absorption capacity of the roots creates a deficiency of $\mathrm{N}$ and possibly other nutrients, thus reducing the content and/or activity of rubisco, decreasing $\mathrm{P}_{\mathrm{N}}$, increasing relative non-stomatal limitation to photosynthesis $\left(\mathrm{L}_{\mathrm{NS}}\right)$ and decreasing relative stomatal limitation $\left(\mathrm{L}_{\mathrm{S}}\right)$ [for definitions see Herrera et al. (2008a)]. The $\mathrm{L}_{\mathrm{NS}}$ could also increase due to down-regulation of PSII. Root TNC content decreases due to both an increase in root anaerobic respiration and a decrease in leaf TNC content due to both decreased $\mathrm{P}_{\mathrm{N}}$ and increased root demand.

During the acclimatized phase, the appearance under full flood of morpho-anatomical adaptations which improve oxygen supply would cause the acclimation. These structures would result in a situation of normoxia for the tree and cause stomatal opening and increased $\mathrm{N}$ and water absorption by the roots because of synthesis of new aquaporins. The increase in $\mathrm{N}$ uptake would cause an increase in rubisco and chlorophyll contents, and $\mathrm{P}_{\mathrm{N}}$. Increased root water absorption would promote stomatal opening. This would also lead to increased $\mathrm{P}_{\mathrm{N}}$. In the process of acclimation of $\mathrm{P}_{\mathrm{N}}$ to full flood, $\mathrm{L}_{\mathrm{NS}}$ decreases and $\mathrm{L}_{\mathrm{S}}$ increases. The role of hormones in this acclimation is presumed but no evidence for it is available. After acclimation, the tree would perform as if flooding did not signify a stress to its physiology, growth or reproduction.

\section{OXYGEN CONCENTRATION UNDER FLOODING AND ITS EFFECTS ON ROOT WATER ABSORPTION AND WATER STATUS}

Oxygen concentration in the water of the Mapire igapó decreases with flooding from $5 \mathrm{mg} \mathrm{L}^{-1}(300 \mu \mathrm{M})$ at the surface of the lake to $2 \mathrm{mg} \mathrm{L}^{-1}(120 \mu \mathrm{M})$ at a depth of $15 \mathrm{~m}$ (details in Herrera et al., $2008 \mathrm{~b}$ ). The $\mathrm{K}_{\mathrm{m}}$ of cytochrome-c oxidase is $14 \mu \mathrm{M}$ (Geigenberger, 2003); Armstrong et al. (2009) give a figure of $0.14 \mu \mathrm{M}$; whichever the values actually is, there is at least a ten times surplus of oxygen before tissues, especially in the roots, become anoxic. Therefore, even in the "worst" situation, plants do not seem to be exposed to severe oxygen stress. Nevertheless, without exact knowledge 


\section{INHIBITION}

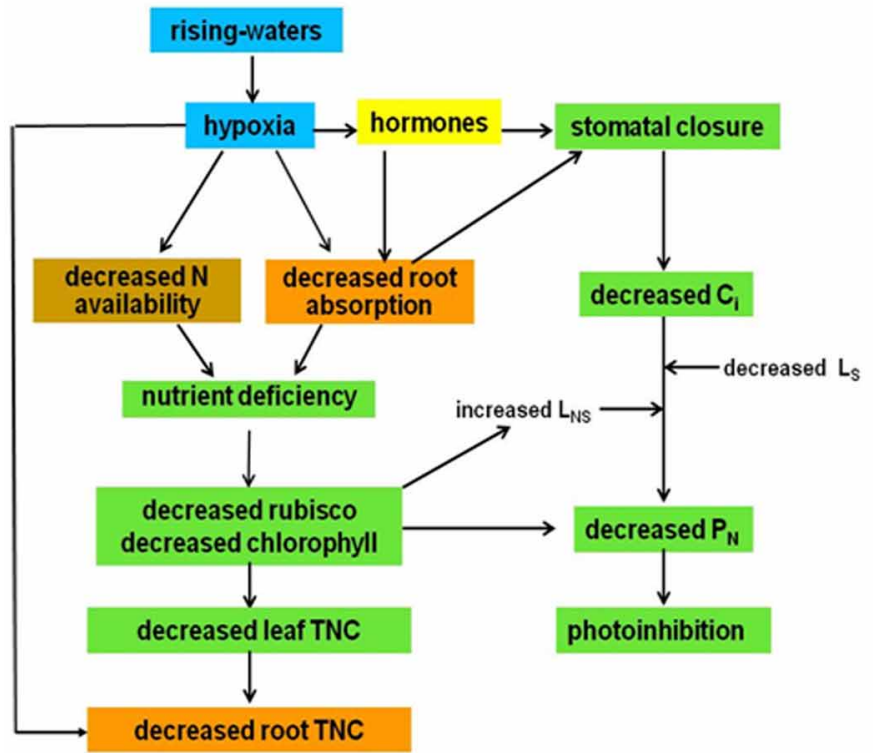

ACCLIMATION

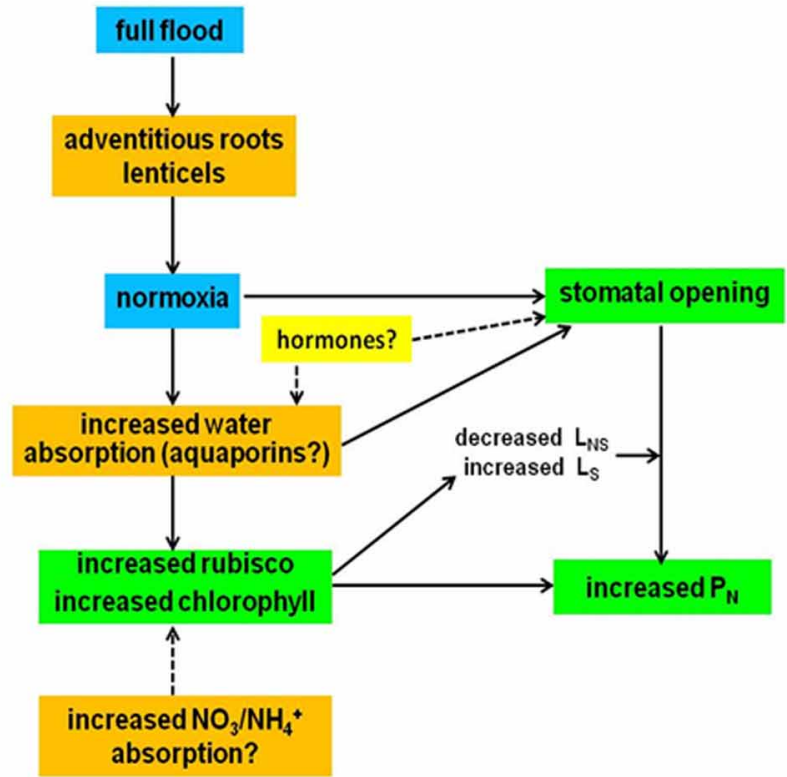

FIGURE 4 | Possible mechanisms of inhibition and acclimation of photosynthesis by flooding. Blue, water; brown, soil; orange, roots and stems; green, leaf; yellow, undetermined.

Table 1 | Changes from drainage (D) to full-flooding (FF) in morning leaf water $(\psi)$ and osmotic $\left(\psi_{\mathrm{s}}\right)$ potential, maximum quantum yield of PSII $\left(F_{v} / F_{m}\right)$, total chlorophyll content $(\mathrm{Chl})$, photosynthetic rate $\left(P_{N}\right)$, stomatal conductance $\left(g_{s}\right)$, and total non-structural carbohydrate contents (TNC) as hexose equivalents of the species indicated.

\begin{tabular}{|c|c|c|c|c|c|c|c|c|}
\hline Species & Season & $\psi$ & $\psi_{s}$ & $F_{v} / F_{m}$ & Chl & 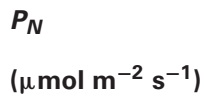 & $\begin{array}{l}g_{s} \\
\left(\mathrm{mmol} \mathrm{m}{ }^{-2} \mathrm{~s}^{-1}\right)\end{array}$ & $\begin{array}{l}\text { TNC } \\
\left(\mathrm{g} \text { hexose } \mathrm{m}^{-2}\right)\end{array}$ \\
\hline \multirow[t]{2}{*}{ A. nitens } & D & -4.27 & -4.13 & 0.79 & 28.9 & 8.1 & 207 & 9.4 \\
\hline & $\mathrm{FF}$ & -0.22 & -3.50 & 0.79 & 22.6 & 12.3 & 399 & 14.4 \\
\hline \multirow[t]{2}{*}{ E. tenuifolia } & $\mathrm{D}$ & -1.53 & -1.66 & 0.83 & 25.6 & 7.6 & 153 & 9.8 \\
\hline & $\mathrm{FF}$ & -0.18 & -1.10 & 0.79 & 23.0 & 4.2 & 196 & 22.1 \\
\hline \multirow[t]{2}{*}{ S. paniculata } & $\mathrm{D}$ & -1.70 & -2.02 & 0.81 & 34.0 & 15.3 & 1161 & 7.7 \\
\hline & $\mathrm{FF}$ & -0.28 & -1.43 & 0.79 & 23.7 & 5.2 & 98 & 27.5 \\
\hline \multirow[t]{2}{*}{ P. ovatifolium } & $\mathrm{D}$ & -2.10 & -2.53 & 0.84 & 24.0 & 13.3 & 269 & 15.4 \\
\hline & $\mathrm{FF}$ & -0.30 & -1.50 & 0.80 & 22.2 & 5.7 & 109 & 26.6 \\
\hline
\end{tabular}

Values are mean. Modified from Rengifo et al. (2005).

of internal root $\mathrm{O}_{2}$ concentration, describing the situation as hypoxia or anoxia is simply speculative. The decrease in the ATP/ADP ratio at decreasing $\mathrm{O}_{2}$ concentration is not paralleled by an increase in the NADPH/NAD ${ }^{+}$ratio until $\mathrm{O}_{2}$ concentration reaches $1 \%$, implying maintenance of aerobic respiration (Geigenberger, 2003).

Since $\mathrm{O}_{2}$ diffuses very slowly in water, the question remains: how much of that $120 \mu \mathrm{M} \mathrm{O}_{2}$ reaches root cells? The occurrence of anaerobic root respiration has been well documented in intolerant as well as tolerant species (Crawford, 1992). Anaerobic respiration has been reported in some tropical flood-tolerant trees (Joly and Crawford, 1982; Parolin and Wittmann, 2010). Indirect evidence for the occurrence of anaerobic metabolism in the Mapire igapó is a notable smell of alcohol near trees of C. laurifolia under FF which is not perceived at any other period of the flooding cycle. The sole direct evidence of alcoholic fermentation in a species from this ecosystem was provided by measurements of increased alcoholic dehydrogenase activity in seedlings of $A$. nitens grown under waterlogging (Izquierdo, 1988). 
Changes in $\mathrm{O}_{2}$ concentration from RW to FF should not totally compromise aerobic respiration; nevertheless, a 60\% decrease in $\mathrm{O}_{2}$ concentration could certainly be reflected in whole-plant and leaf performance, as seems to happen. This marked decrease in $\mathrm{O}_{2}$ concentration would be alleviated after a short period under flooding by the production of new morpho-anatomical structures and the operation of physiological and biochemical processes, such as pressurized gas transport and aquaporin synthesis.

In an ingenuous approach to the issue of aquaporin influence on root water absorption, McElrone et al. (2007) accessed through caves the fine roots of trees growing at a depth of $18 \mathrm{~m}$ and determined that aquaporin activity contributed up to $45 \%$ of hydraulic conductivity. The collection of fine roots and measurement of aquaporin activity in flooded trees should help understanding the acclimation of aerial responses to flooding.

The improvement of oxygen transport to the roots by pressurized gas transport, experimentally demonstrated in some temperate tree species (Grosse et al., 1992) and tropical flood-tolerant herbs (Konnerup et al., 2011), is one of the known adaptations to flooding. In saplings of five Amazonian tree species, internal aeration of the roots was improved under conditions of pressurized gas transport as shown by measurements of oxygen exchange between root and rhizosphere. Using a tracer gas, Graffmann et al. (2005) showed gas permeability of transport pathways between the stem base and the roots of these saplings and concluded that pressurized gas transport significantly contributes to internal aeration of roots.

In intolerant species, the initial reduction under flooding in $\mathrm{g}_{\mathrm{s}}$ is accompanied by decreased $\psi$ and leaf water status (Crawford, 1982; Ruiz-Sánchez et al., 1996). In trees of the Mapire igapó, $\psi$ was found to increase with flooding (Table 1), suggesting that flooding does not cause water deficit in these trees. Weak or no relationship between $g_{s}$ and $\psi$ was found, except for $A$. nitens $\left(r^{2}=0.43\right)$, the one species growing along the gradient in the Mapire igapó that suffers from water deficit during the dry season. Since $g_{s}$ diminished during the earlier stages of flooding, trees behaved as iso-hydric species. Similar increases with flooding in $\psi$ without decreased $\mathrm{P}_{\mathrm{N}}$ and, presumably, $\mathrm{g}_{\mathrm{s}}$ were found in the evergreen várzea tree $P$. glomerata (Armbrüster et al., 2004). These results suggest a direct effect of flooding on gas exchange independent from water status.

The ABA content of leaves and xylem sap extracted under positive pressure increased from D to RW and FF in C. laurifolia and $P$. orinocoensis, together with the known decrease in $\mathrm{g}_{\mathrm{s}}$, suggesting a positive relationship between ABA and stomatal closure. In fact, the regression between $\mathrm{ABA}$ and $\mathrm{g}_{\mathrm{s}}$ was linear with $r^{2}=0.98$ (Rengifo et al., 2006). A similar relationship was found in flooded tomato plants (Else et al., 1995). These results are subject to revision, since to obtain meaningful changes in sap ABA content, care must be taken when collecting sap, as overpressurizing stems may bring out ABA located in roots (Jackson, 1997), thus portraying an erroneous picture of ABA influence on $g_{s}$ during the flooding cycle. No relationship was found in flooded tomato plants between stomatal closure and inhibition of gibberellin or cytokinin export (Else et al., 2009). Possible methodological errors in determination of data by Rengifo et al.
(2006) may render their interpretation erroneous; nevertheless, they open interesting research avenues in tolerant trees.

Trees under flood in the igapó showed values of leaf osmotic potential $\left(\psi_{\mathrm{s}}\right)$ consistently lower than those of $\psi$ (Table 1), suggesting the occurrence of osmotic adjustment (Rengifo et al., 2005); an osmotic adjustment of $0.26 \mathrm{MPa}$ was shown to take place in flooded citrus seedlings (García-Sánchez et al., 2007). In four of the igapó species studied, soluble sugars contributed significantly to the decrease in $\psi_{s}$; in A. nitens, the contribution was low presumably because nitrogenous compounds supplied by nitrogen fixation in this legume made a significant contribution (Fernández et al., 1999). The accumulation in leaves of osmotically active metabolites, mostly sugars, may be a mechanism whereby these trees tolerate flooding by increasing turgor potential, which allows the resumption of high $\mathrm{g}_{\mathrm{s}}$ and $\mathrm{P}_{\mathrm{N}}$.

When it is due to water transport from the roots to the atmosphere and not to replenishment of reservoirs, xylem sap flux may indicate the ability of roots to absorb water. In trees of $C$. laurifolia, sap flux changed seasonally; relative to the highest values measured during drainage in November, sap flux was $47 \%$ at the dry season, decreasing to $25 \%$ at rising-waters and resuming $49 \%$ under full flood [calculated from Herrera et al. (2008b)].

Since at RW dawn $\psi$ remained high, it became apparent that the initial stages of flooding imposed a restriction to sap flux unrelated to water deficit. The decrease at RW in highest daytime sap flux was due to reduced leaf-specific hydraulic conductivity, whereas the recovery of daytime sap flux observed 1.5 months later was correlated to an increase in leaf-specific hydraulic conductivity, and attributed to acclimation.

The decrease with flooding in root hydraulic conductivity has been documented and attributed to cytoplasmic acidification due to increased $\mathrm{CO}_{2}$ concentration and inhibition of aquaporin activity (Aroca et al., 2011). Evidence of this has been gathered in herbs and shrubs, mainly of agronomic interest and floodintolerant, but no data are still available on flood-tolerant trees. Early flooding in the Mapire igapó apparently inhibited water absorption by roots and this inhibition was overcome later on at a higher water column through an acclimation process possibly involving the improvement of internal aeration by adventitious roots or by synthesis of new aquaporins.

A substantial night-time flux accompanied by nocturnal stomatal aperture was found in C. laurifolia under FF (Herrera et al., 2008b). Similar observations have been made in plants of other species and from other environments (e.g., arid) and a role for night-time transpiration in $\mathrm{N}$ absorption has been suggested (Snyder et al., 2008). Why would flood-tolerant trees implement a mechanism for nutrient acquisition during the night remains to be elucidated. One possibility is that the development of positive nocturnal root pressure generated by active transport of ions into the xylem, together with open stomata, results in increased sap flux and nutrient supply to the shoot.

\section{STOMATAL CLOSURE AND REDUCTION IN P $_{\mathbf{N}}$ UNDER FLOODING ARE REVERSIBLE}

In three out of four tropical tree species that grow on drained soils in drylands, experimentally subjected to waterlogging (Lopez and Kursar, 1999), $g_{s}$ diminished $30 \%$ on average, one of the species, 
Prioria copaifera, showing no change. In this species $\mathrm{P}_{\mathrm{N}}$ was significantly reduced after 45 days of experimental flooding but, in contrast to the other three species, resumed drained values after 90 days of flooding, the authors deeming this a flood-tolerant species.

In Table 2, values of maximum $\mathrm{P}_{\mathrm{N}}$ of evergreen trees in a Brazilian várzea and the Mapire igapó are compared during the drained and flooded periods. None of the várzea species showed changes with flooding, whereas in the igapó $\mathrm{P}_{\mathrm{N}}$ increased in all the species. The observation that although igapó waters are poorer and more acidic than várzea waters, average maximum $\mathrm{P}_{\mathrm{N}}$ at FF was similar between wetlands merits further comparative research.

The reversal of diminished $g_{s}$ to values under drainage was associated in C. laurifolia and S. paniculata to the growth of adventitious roots (Figure 5). The occurrence with flooding of adventitious roots and hypertrophied lenticels has been reported in trees of several species in the central Amazonian floodplains (Parolin, 2001). Amelioration of leaf gas exchange through improvement in aeration by adventitious roots and hypertrophied lenticels has been reported in temperate tolerant species (Kozlowski, 1984) such as L. laricina, in which such roots increase root hydraulic conductivity apart from improving oxygenation (Islam and Macdonald, 2004).

\section{FLOODING AND PHOTOINHIBITION}

Despite decreased $g_{s}$ and $P_{N}$ and high radiation and air temperature, emerged leaves of tolerant trees do not become photoinhibited during RW, when decreased $\mathrm{P}_{\mathrm{N}}$ is often observed. Values of maximum quantum yield of PSII, $\mathrm{F}_{\mathrm{v}} / \mathrm{F}_{\mathrm{m}}$ (Table 1), were always higher than 0.70 , the threshold proposed by BolhàrNordenkampf and Öquist (1993) for determining that photoinhibition occurs. The $\mathrm{F}_{\mathrm{v}} / \mathrm{F}_{\mathrm{m}}$ was also higher than 0.70 in plants of S. paniculata growing in the Solimões River várzea that had been submerged at $1 \mathrm{~m}$ in the dark for 6 months, and leaves submerged deeper did become photoinhibited $\left(F_{v} / F_{m}=0.20\right)$ but regained high values several weeks later upon re-emergence (Waldhoff et al., 2002).

In the Mapire igapó, most leaves of plants of S. paniculata and $P$. ovatifolium under FF for approximately 6 months may become photoinhibited because the entire tree is covered with a 15-m-high water column. This, together with a reduction of $50 \%$ in radiation at a depth of $60 \mathrm{~cm}$ in June (Fernández et al., 1999), could mean that deeply submerged leaves do reduce $\mathrm{P}_{\mathrm{N}}$ to zero. Leaves of $S$. paniculata that developed at D and remained submerged for approximately 4 months were fully functional when they emerged at FW (Fernández et al., 1999), indicating that they were not negatively affected by submergence.
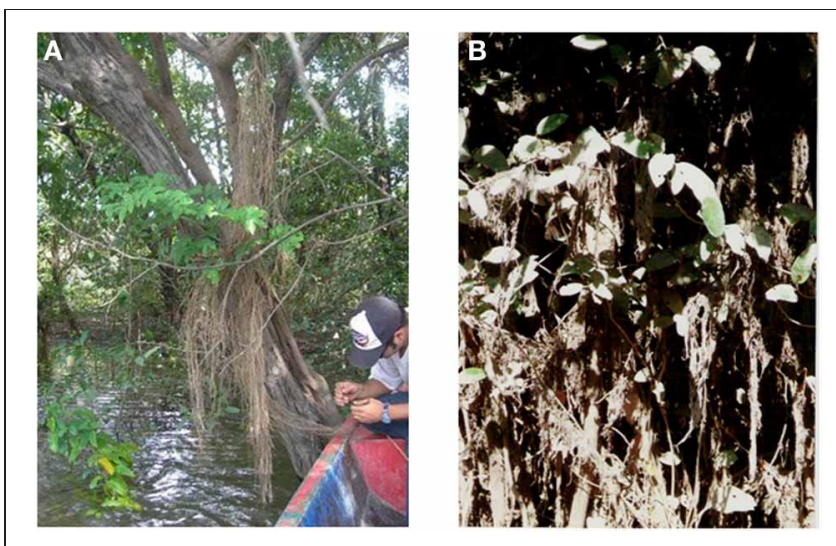

FIGURE 5 | Adventitious roots observed in October at falling-waters in trees of: (A) Campsiandra laurifolia and (B) Symmeria paniculata. Note in (B) the mud deposits on leaves from previous flood.

Table 2 | Maximum values of photosynthetic rate in evergreen trees growing in a várzea and an igapó during drainage (D) and flooding (FF).

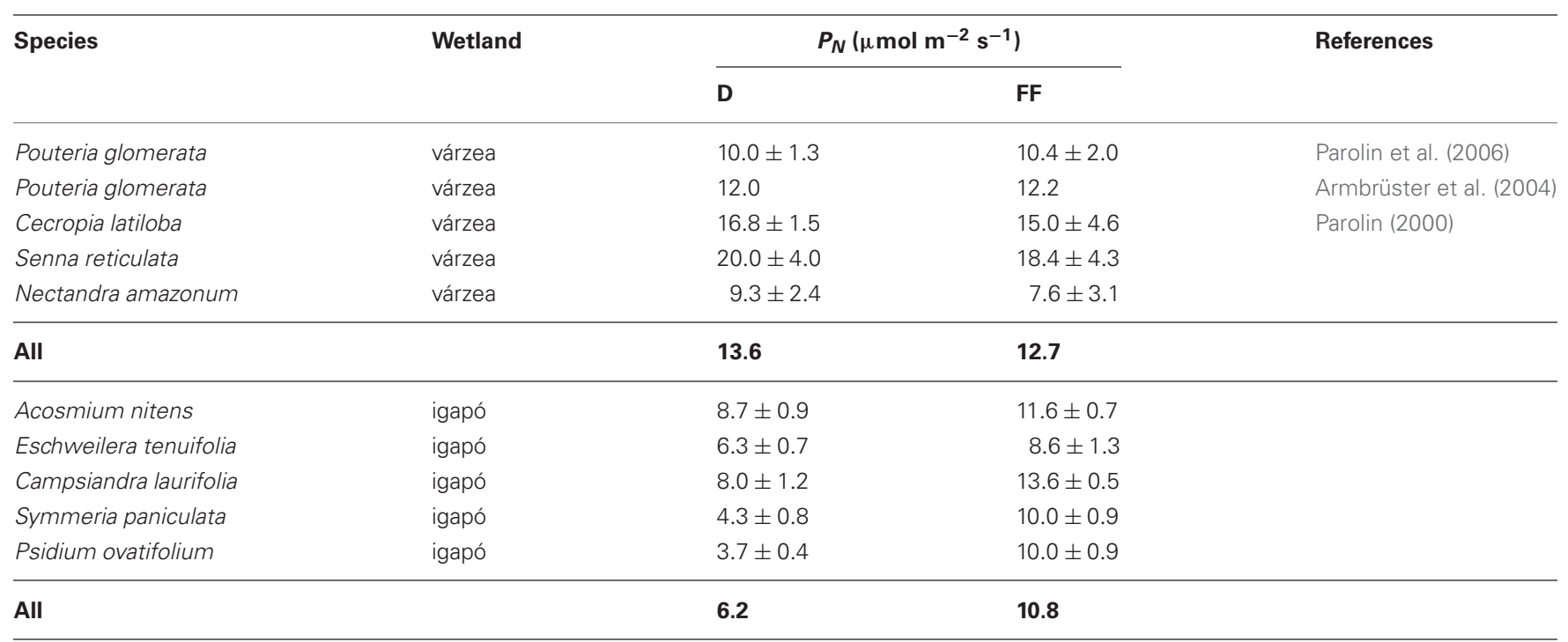

Values are mean \pm SE for species and mean for each wetland (in bold). Data for the igapó are means of value reported by Fernández et al. (1999), Rengifo et al. (2005), and Herrera et al. (2008a,b). 


\section{REVERSIBLE REDUCTION IN $P_{\mathrm{N}}$ UNDER FLOODING IS ASSOCIATED TO} CHANGES IN STOMATAL AND NON-STOMATAL LIMITATIONS

It has not been systematically examined whether in flood-tolerant trees $\mathrm{P}_{\mathrm{N}}$ decreases under flood due to decreased $\mathrm{g}_{\mathrm{s}}$ only. In flooded plants of the tropical species Genipa americana, photosynthesis was co-limited by stomatal and non-stomatal factors (Mielke et al., 2003). In seedlings of the non-tolerant temperate species Nothofagus menziesii and N. solandri, $\mathrm{P}_{\mathrm{N}}$, $\mathrm{g}_{\mathrm{s}}$, and non-stomatal conductance, i.e., mesophyll conductance plus carboxylation efficiency, decreased markedly in response to waterlogging (Sun et al., 1995). In the igapó species P. orinocoensis, carboxylation efficiency in experimentally submerged seedlings decreased $70 \%$ and $\mathrm{CO}_{2}$-saturated $\mathrm{P}_{\mathrm{N}} 61 \%$ relative to drained seedlings (Fernández, 2006), indicating colimitation of photosynthesis by stomatal and non-stomatal factors.

In order to determine whether in species of the Mapire igapó $\mathrm{P}_{\mathrm{N}}$ is reduced due to changes in $\mathrm{L}_{\mathrm{S}}$ and $\mathrm{L}_{\mathrm{NS}}$, response curves of $\mathrm{P}_{\mathrm{N}}$ to $\mathrm{C}_{i}$ were done (Figure 6). Photosynthetic capacity was affected by flooding, as indicated by variations in $\mathrm{CO}_{2}$-saturated $\mathrm{P}_{\mathrm{N}}$ (Figures 6, 7). The $\mathrm{L}_{\mathrm{S}}$ (the difference in $\mathrm{CO}_{2}$-saturated $\mathrm{P}_{\mathrm{N}}$ and $\mathrm{P}_{\mathrm{N}}$ at ambient $\mathrm{CO}_{2}$ concentration divided by the former) decreased, whereas $\mathrm{L}_{\mathrm{NS}}\left(\mathrm{CO}_{2}\right.$-saturated $\mathrm{P}_{\mathrm{N}}$ at a given time divided by the maximum $\mathrm{CO}_{2}$-saturated $\mathrm{P}_{\mathrm{N}}$ ) increased relative to drainage
(Figure 7). The increase in $\mathrm{L}_{\mathrm{NS}}$ was related to a decrease in total soluble protein (TSP), an indirect measure of rubisco content, and chlorophyll content (Figure 7). Nevertheless, it was previously reported that rubisco content was similar in emerged and submerged leaves of $P$. ovatifolium and higher in submerged than emerged leaves of S. paniculata (Fernández et al., 1999), indicating no loss of rubisco due to submergence or even flooding. It remains to determine whether this maintenance of rubisco content is a general response in the rest of the species in the igapó. A $54 \%$ change in $P_{N}$ was due to changes in $g_{s}$, confirming that the limitation imposed by flooding to $\mathrm{P}_{\mathrm{N}}$ was not only stomatal (Herrera et al., 2008a).

Soil $\mathrm{NO}_{3}^{-}$content in the Mapire igapó decreases markedly during the flooded period, whereas $\mathrm{NH}_{4}^{+}$content progressively increases until drainage (Barrios and Herrera, 1994). The decrease in $\mathrm{NO}_{3}^{-}$content could be relevant for metabolism in nonleguminous but not in leguminous trees. Approximately $30 \%$ of the species in the Mapire igapó, including A. nitens and C. laurifolia, are legumes (Rosales, 1988). Setting aside differences in habit and habitat, the positive effect in the pasture legume Lotus corniculatus of low $\mathrm{O}_{2}$ concentration on nodulation, $\mathrm{N}_{2}$ fixation and growth reported by James and Crawford (1998) suggests that a similar response of $\mathrm{N}_{2}$ fixation to low $\mathrm{O}_{2}$ could be expected in flood-tolerant legume trees.

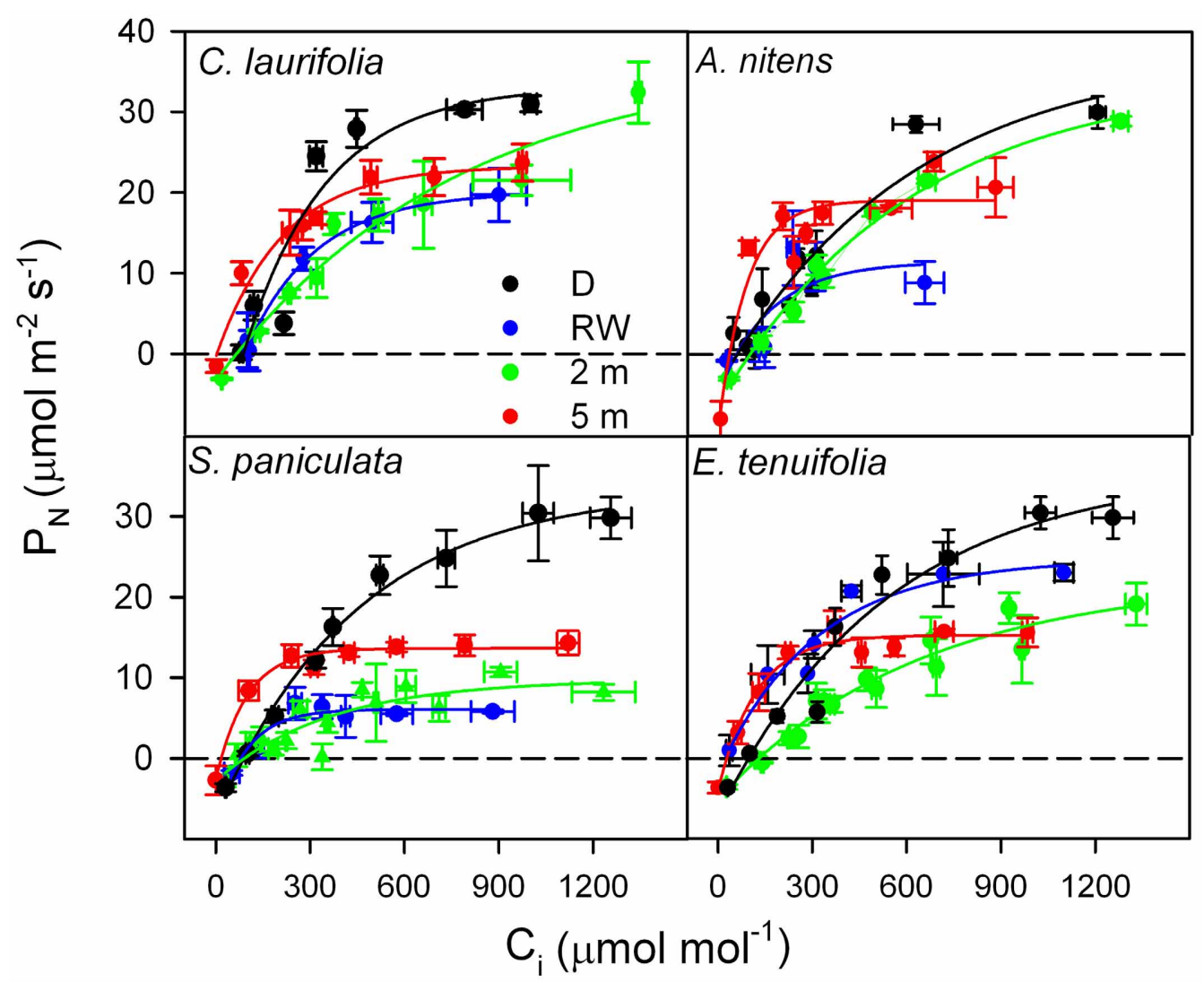

FIGURE 6 | Response curves of photosynthetic rate to intercellular $\left[\mathrm{CO}_{2}\right]$ in the species indicated during drainage (black), rising-waters (blue), flooding by 2-m water column (green), and full flood by 5-m water-column (red). Modified from Herrera et al. (2008a). 


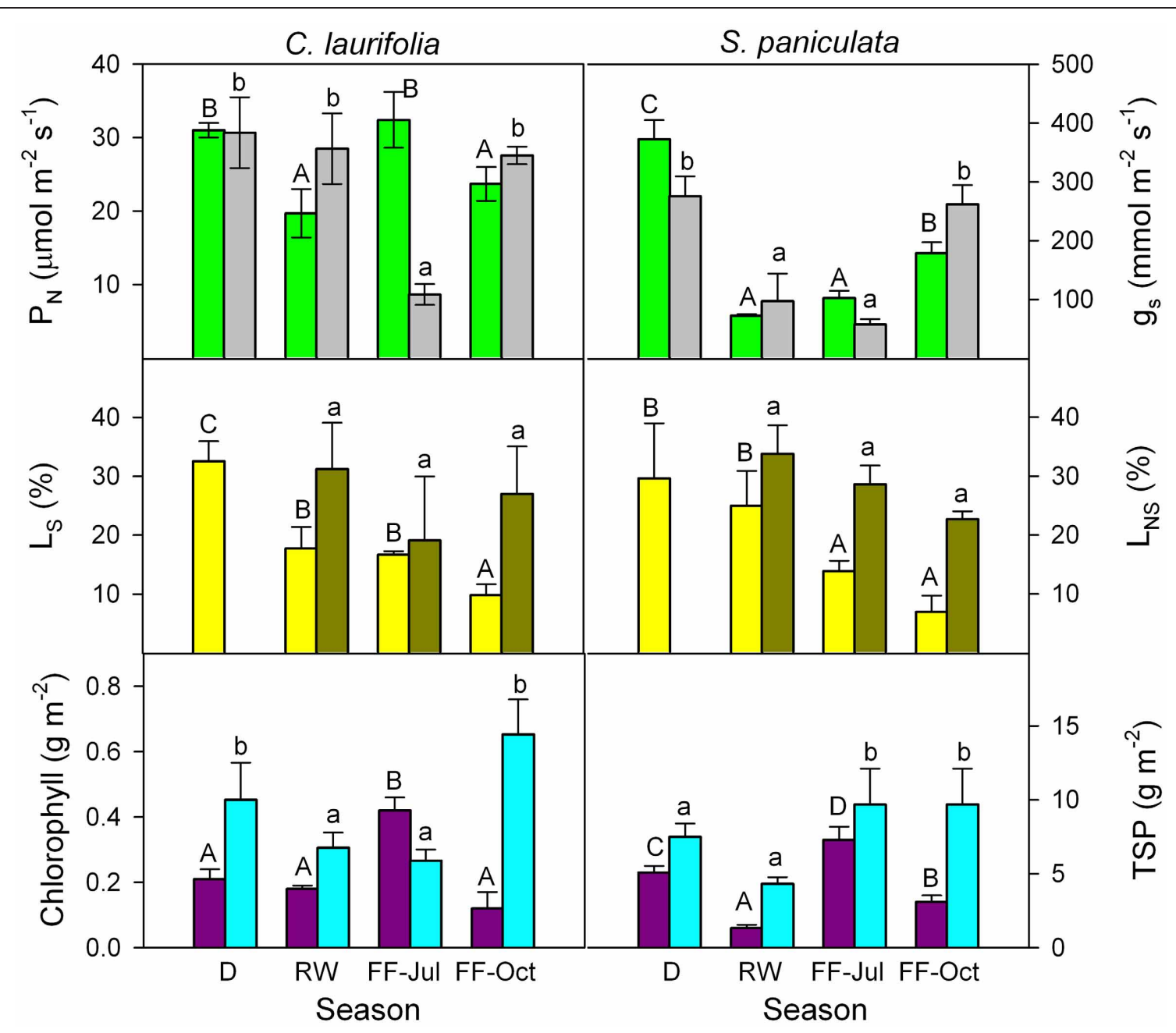

FIGURE 7 | Seasonal changes in $\mathrm{CO}_{2}$-saturated photosynthetic rate (green), stomatal conductance at ambient $\mathrm{CO}_{2}$

concentration (gray), relative stomatal (yellow) and non-stomatal (dark green) limitations of photosynthesis, chlorophyll (purple), and total soluble protein (cyan) content of the species indicated. D, drainage; RW, rising-waters; FF-Jul, full flood in July; and FF-Oct, full flood in October. Modified from Herrera et al. (2008a).
An increase with flood in $\mathrm{L}_{\mathrm{NS}}$ in legumes would not necessarily involve a decrease in rubisco content due to low $\mathrm{N}$ supply, since legumes do not depend on $\mathrm{NO}_{3}^{-}$availability for protein synthesis. Instead, the increase in $\mathrm{L}_{\mathrm{NS}}$ and decrease in TSP of legumes of the Mapire igapó could be due to low availability/absorption of other nutrients, extremely low $\mathrm{O}_{2}$ concentration in the nodules or toxicity caused by reduced ions. Uptake of $\mathrm{NO}_{3}^{-}$and $\mathrm{NH}_{4}^{+}$by saplings of Fagus sylvatica (flood-intolerant) was severely inhibited by waterlogging, whereas in Populus tremula $\times P$. alba (flood-tolerant) absorption of both $\mathrm{N}$ forms was unaffected (Kreuzwieser et al., 2002). We have no information on which form of nitrogenous compounds trees, whether legumes or non-legumes, absorb at D or FF.

Leaf N content of species in the Mapire igapó (Rosales, 1988) was similar to that in the Rio Negro igapó (Parolin et al., 2002), with an average of $2 \%$ (by dry mass). No data are available for seasonal variations in leaf $\mathrm{N}$ content in the Mapire igapó; in the Rio
Negro igapó, content varied between the drained and the flooded phases, with no consistent trend, since in some species content decreased, whereas in others it increased with flooding. Changes in content were related to leaf development, content being higher in new leaves which flushed mostly during the flooded period. Therefore, the reduction in soil $\mathrm{N}$ availability is not apparently reflected in leaf $\mathrm{N}$ content.

\section{LEAF CARBOHYDRATE BALANCE CHANGES DURING FLOODING}

Information on changes in TNC content of flood-tolerant species is scant. In seedlings of the várzea species Himatanthus sucu$u b a$ experimentally subjected to submergence in the dark, root starch content diminished while alcoholic dehydrogenase activity remained relatively constant after an initial increase (Ferreira et al., 2009). It has been proposed that flood tolerance is proportional to the capacity of roots for TNC storage (Crawford, 1992). In the Mapire igapó, difficulty in accessing roots has impeded the 
determination of root TNC content; therefore, leaf TNC balance has been used as a surrogate measure.

Leaves of all the trees studied in the Mapire igapó accumulated TNC under flooding (Table 1) but this accumulation was not always related to a higher $\mathrm{P}_{\mathrm{N}}$. Similarly, flooded seedlings of the temperate tolerant species L. laricina showed a marked increase in shoot starch after 27 days of flooding, as opposed to seedlings of the intolerant species Picea mariana (Islam and Macdonald, 2004), which suggests that starch accumulation in leaves is a tolerance mechanism. In our investigation, TNC accumulation began at RW, when $\mathrm{P}_{\mathrm{N}}$ of all the species was lower than the maximum (Table 1). This suggests that photosynthates could not be translocated to other sinks and the mechanisms responsible for alleviating hypoxia had not begun operating. In all the species TNC content began to decrease at FF or FW, coinciding with the resumption of high $\mathrm{P}_{\mathrm{N}}$ (Rengifo et al., 2005). Enhanced starch and sugar accumulation was observed in woody species under flooding, suggesting that this is a consequence of reduced phloem translocation from shoot to root (Kreuzwieser et al., 2004).

\section{SIGNIFICANCE OF UNDER-WATER PHOTOSYNTHESIS FOR WHOLE-PLANT C BALANCE}

In the Mapire igapó, some of the tree species maintain live leaves submerged for as long as 6 months. Submerged leaves brought to the air showed values of $\mathrm{P}_{\mathrm{N}}$ similar to emerged leaves (Figure 8), indicating that leaves may be photosynthetically active under water.

The significance for whole-tree physiology of underwater photosynthesis has not been examined yet; the energy-costly process

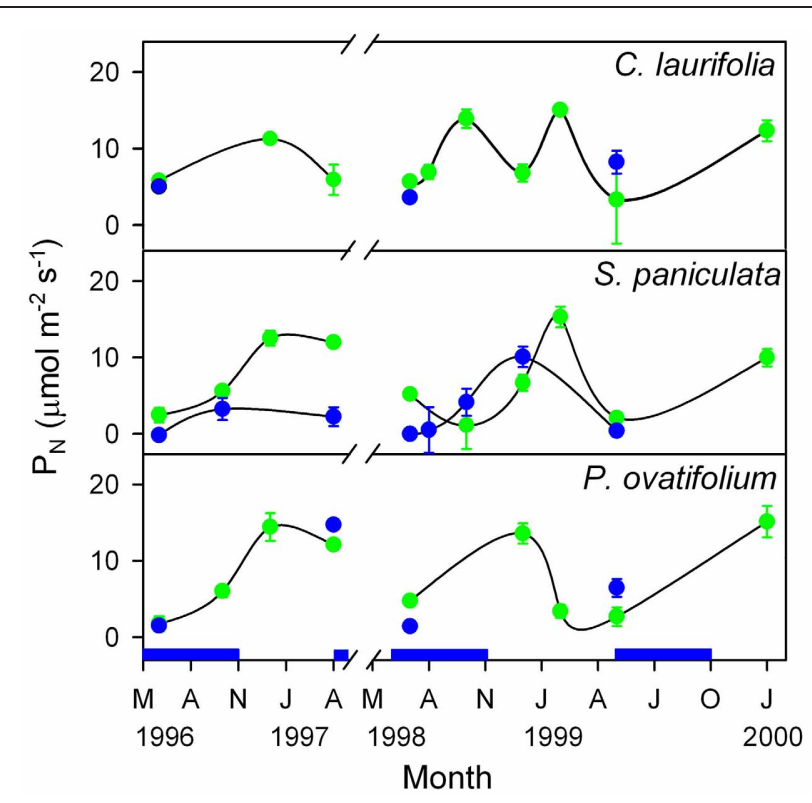

FIGURE 8 | Seasonal changes in photosynthetic rate of emerged and submerged leaves of the species indicated. Green circles, emerged leaves; blue circles, submerged leaves. The blue indicates the duration of the flood period. Modified from Herrera et al. (2001). of maintaining live leaves under water may be compensated by continued $\mathrm{O}_{2}$ supply to the roots produced by the photosynthetic activity of these submerged leaves. Significant daily oscillations in TNC content of submerged leaves of $P$. ovatifolium and C. laurifolia that were 53 and $131 \%$ of those in aerial leaves, respectively (Fernández et al., 1999), support the hypothesis that these leaves are in effect photosynthesizing underwater. Additionally, the balance could resided in having leaves that are fully functional when waters fall; in this case, the payback would lie in a higher wholetree leaf area, hence higher productivity, as opposed to trees which do not maintain live leaves under water.

The occurrence of radial oxygen loss in submerged plants has been interpreted as evidence of photosynthetic $\mathrm{O}_{2}$ production and transport to roots (Armstrong et al., 2006), demonstrating a positive contribution of underwater photosynthesis to wholeplant survival.

Indirect evidence of the occurrence of underwater photosynthesis is contradicted by the finding in seedlings of $P$. orinocoensis that $\mathrm{O}_{2}$ consumption by submerged leaves measured with an $\mathrm{O}_{2}$ electrode became almost zero after 12 days and remained so for 45 days, while emerged leaves, although continually reducing $\mathrm{P}_{\mathrm{N}}$ and $\mathrm{g}_{\mathrm{s}}$ during 45 days of treatment, had values of $\mathrm{P}_{\mathrm{N}}$ after 12 days of $70 \%$ the value at the beginning of flooding (Fernández, 2006). The author argues that such responses would be expected from seedlings in the field because to them, in contrast to adult trees, flooding would be abrupt and stressful.

The case of S. paniculata and P. ovatifolium is particularly interesting, because plants of these species are covered by water earlier and remain submerged longer than other species in the igapó forest. Most of the foliage of these plants remains under water at $25 \%$ of incident radiation, yet is fully functional as soon was waters fall (Fernández et al., 1999; Rengifo et al., 2005). An important issue related to the possible underwater photosynthetic activity is that of whether enough $\mathrm{CO}_{2}$ is available. The $\mathrm{CO}_{2}$ concentration calculated at the $\mathrm{pH}$ and alkalinity of the water from data of Vegas-Vilarrúbia and Herrera (1993b) was at any season one order of magnitude higher than the $\mathrm{K}_{\mathrm{m}}\left(\mathrm{CO}_{2}\right)$ of rubisco (Fernández et al., 1999); therefore, $\mathrm{CO}_{2}$ availability would not be a limiting factor as long as the gas diffused into the leaf.

\section{LEAF ANATOMY REMAINS UNCHANGED UNDER FLOODING}

In many tolerant was well as intolerant species, flooding leads to a programmed destruction of cells in the leaves as well as stems that ends in the formation of aerenchyma, in a process designed to improve aeration of organs. In the Mapire igapó, as observed in tolerant trees of the Solimões River igapó (Waldhoff and Furch, 2002; Waldhoff, 2009), leaf anatomy remained practically unchanged regardless of phase of the flood cycle (Herrera et al., 2009; Figure 9). Emerged leaves under FF are apparently new and, using lack of sediment deposition as an indicator, produced by branches not covered by water. No signs of branch or petiole elongation under flooding, a phenomenon observed in flooded herbs (Bailey-Serres and Voesenek, 2008), have been observed but their occurrence may not be ruled out without detailed time-series on labeled individuals.

A xeromorphic leaf anatomy, such as described for droughttolerant trees (Roth and Lindorf, 1991), was observed, with 


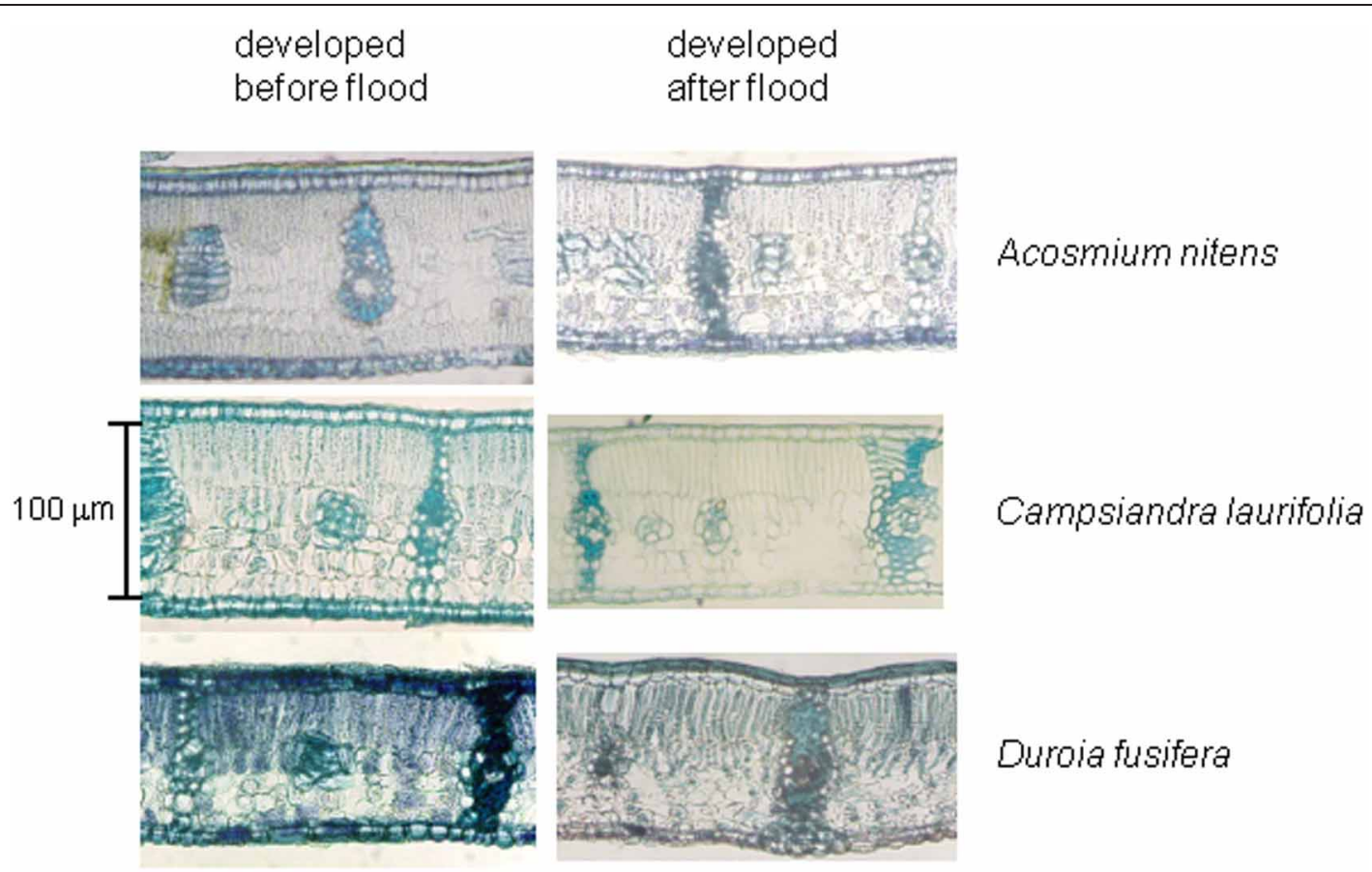

FIGURE 9 | Cross-sections of emerged leaves of the species indicated produced during drainage and after full flooding. The sections were stained with toluidine blue. Modified from Herrera et al. (2009).

abundant sclerenchyma separating mesophyll sections into areoles, and no aerenchyma formation (Herrera et al., 2009). The significance of the occurrence of heterobaric leaves in this environment is unclear and merits further investigation.

Leaves collected in the Mapire igapó at FW from trees on drained soil and trees under flooding had few differences in proportional tissue thickness, the sole significant ones being a reduction in whole-leaf thickness of E. tenuifolia, P. orinocoensis, and $S$. paniculata and a change in relative thickness of parenchymata in E. tenuifolia (Herrera et al., 2009). These results contrast with observations done on the tropical species Alchornea triplinervia (Roças and Scarano, 2001), where palisade and spongy parenchymata of flooded plants growing in the field were 1.4 times as thin as those in unflooded plants.

Specific leaf area (SLA $=$ area/mass) decreased with flooding, being higher in young than mature leaves and similar in mature emerged and submerged leaves (Herrera et al., 2009). In Rumex palustris, a wetland herbaceous plant, leaf thickness and SLA were 20 and 58\% lower in submerged than emerged leaves (Mommer et al., 2005). This was attributed the function of facilitating $\mathrm{O}_{2}$ diffusion through the liquid phase into the mesophyll. In trees of the Mapire igapó the acclimation to flooding of leaf gas exchange may involve an increase in mesophyll conductance to $\mathrm{CO}_{2}$ in spite of augmented dry mass per area, which may have increased due to increased total soluble protein (Herrera et al., 2008a).

\section{ECO-PHYSIOLOGICAL AND ECOLOGICAL CONSIDERATIONS}

The occurrence in all the species of the Mapire igapó examined of values of $g_{s}$ and $P_{N}$ as high under $D$ as under FF suggests that even though these species are indeed tolerant to flooding, they thrive under drainage as long as the soil is wet. This is supported by the finding that in C. laurifolia, A. nitens, P. orinocoensis, and P. ovatifolium, a strong relationship between the formation of new wood rings and the fluctuation of the river level during the non-flooded months suggested that an increase in the river water level during drainage promoted growth probably because of better access to ground water (Dezzeo et al., 2003). This could be interpreted as meaning that these species chose to occupy wetlands because of the competitive advantages tolerance gives them, not because of a strict requirement of flooding to grow. Trees of $A$. nitens and C. laurifolia grow vigorously at the savanna-end of the gradient, where they experience flooding of low height and short duration, and trees of Andira inermis, among others, grow to very large size in areas of the savanna far removed from the igapó. The apparent lack of need for flooding in these species contrasts with the requirement of salt in other flood-tolerant trees, mangroves, in many of which $\mathrm{P}_{\mathrm{N}}$ and growth increase in response to salinity up to an optimum (Wang et al., 2011).

Flooding is frequently considered a generalized stress (e.g., Jackson and Colmer, 2005; Bailey-Serres and Voesenek, 2008; Perata et al., 2011), even when dealing with flood-tolerant plants (Parolin and Wittmann, 2010). In agreement with Otte (2001), I argue here that flooding would be stressful if it were not normally encountered by plants and that waterlogging and flooding are not stressful to wetland plants, but only to non-adapted dry land plants. The aim in this argument is not semantic; rather, I have endeavored to demonstrate that initial "negative" responses to flooding of tolerant trees are part of the adaptation. 


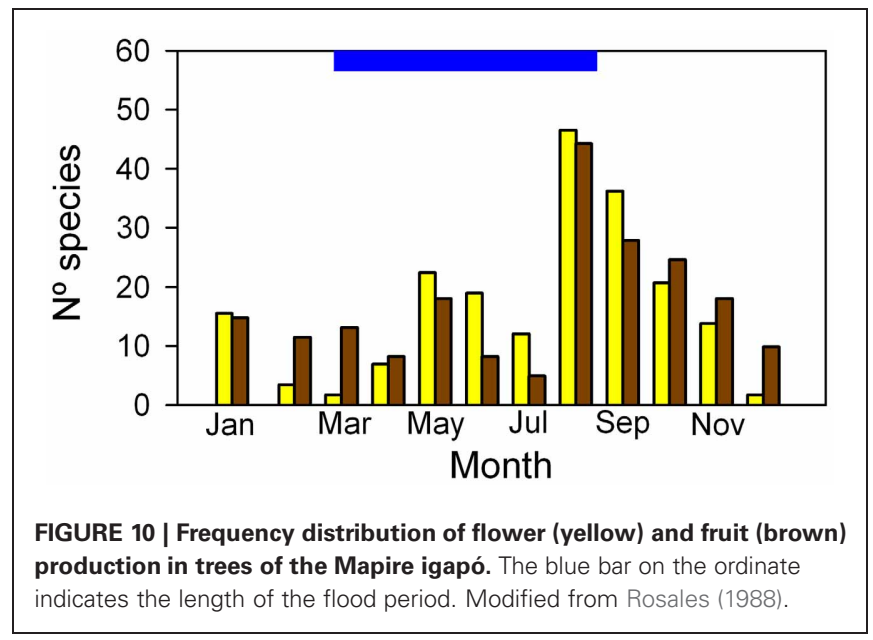

Additionally, the mere observation that $\psi$ increases when waters rise supports the idea of not describing flooding as a stress to tolerant plants.

Of the 85 species identified in the Mapire igapó, $85 \%$ flowered and $73 \%$ set fruit during the flooded period, mostly during August-September (Figure 10). Detailed time-series of leaf production and reproduction in conspecific trees growing under flood and in dry lands would be welcome when dealing with flood tolerance. Together with high $\mathrm{P}_{\mathrm{N}}$ values and maintenance of leaf area, the reproductive phenological behavior seems to indicate

\section{REFERENCES}

Armbrüster, N., Müller, E., and Parolin, P. (2004). Contrasting responses of two amazonian floodplain trees to hydrological changes. Ecotropica 10, 73-84.

Armstrong, J., Jones, R. E., and Armstrong, W. (2006). Rhizome phyllosphere oxygenation in Phragmites and other species in relation to redox potential, convective gas flow, submergence and aeration pathways. New Phytol. 172, 719-731.

Armstrong, W., Webb, T., Darwent, M., and Beckett, P. M. (2009). Measuring and interpreting respiratory critical oxygen pressures in roots. Ann. Bot. 103, 281-293.

Aroca, R., Porcel, R., and Ruiz-Lozano, J. M. (2011). Regulation of root water uptake under abiotic stress conditions. J. Exp. Bot. 63, 43-57.

Bailey-Serres, J., and Voesenek, L. A. C. J. (2008). Flooding stress: acclimations and genetic diversity. Annu. Rev. Plant Biol. 59, 313-339.

Barrios, E., and Herrera, R. (1994). Nitrogen cycling in a Venezuelan tropical seasonally flooded forest: soil nitrogen mineralization and nitrification. J. Trop. Ecol. 10, 399-416.
Batzli, J. M., and Dawson, J. O. (1997). Physiological and morphological responses of red alder and Plant. 99, 653-663.

Bolhàr-Nordenkampf, H. R., and Öquist, G. (1993). "Chlorophyll fluorescence as a tool in photosynthesis research," in Photosynthesis and Production in a Changing Environment, eds D. O. Hall, J. M. O. Scurlock, H. R. BolhàrNordenkampf, R. C. Leegood, and S. P. Long (London: Chapman and Hall), 193-206.

Colmer, T. D., and Voesenek, L. A. C. J. (2009). Flooding tolerance: suites of plant traits in variable environments. Funct. Plant Biol. 36, 665-681.

Crawford, M. M. (1992). Oxygen availability as an ecological limit to plant distribution. Adv. Ecol. Res. 23, 93-185.

Crawford, R. M. M. (1982). "Physiological responses to flooding," in Encyclopedia of Plant Physiology, eds A. Pirson and M. H. Zimmermann (Berlin: Springer-Verlag), 453-477.

Dezzeo, N., Worbes, M., Ishii, I., and Herrera, R. (2003). Annual tree rings revealed by radiocarbon sitka alder to flooding. Physiol. that flooding increases fitness through its two components, survival and fecundity. This supports the idea that flooding, far from constituting a stress to these wetland plants, is a natural and necessary part of the suite of environmental variables that make their presence in this ecosystem possible.

\section{CONCLUDING REMARKS AND FUTURE PERSPECTIVES}

Thus far, a wealth of information is available on the responses to flood of leaf gas exchange and leaf and whole-plant water status but we know very little about mechanisms underlying such responses. The following is important to solve this issue:

1. In order to gain knowledge on plant tolerance to hypoxia/anoxia in tropical tolerant trees, the morphoanatomical, biochemical and molecular characteristics of roots must be literally unearthed. De novo synthesis of root aquaporins and the occurrence of pressurized $\mathrm{O}_{2}$ transport could help explain acclimation to flooding. Difficulty in accessing the root system of large trees has hindered progress in this area and data from more feasible experiments with seedlings may not necessarily be extrapolated to adult trees.

2. Examination of the hormonal balance of these trees under flooding seems imperative; preliminary data on leaf and xylem ABA contents point in the direction of promising research.

3. Long-term phenological observations under continually drained conditions should help elucidate whether these species are dependent on flooding for the completion of their life cycle. dating in seasonally flooded forest of the Mapire River, a tributary of the lower Orinoco River, Venezuela. Plant Ecol. 168, 165-175.

Drew, M. C. (1997). Oxygen deficiency and root metabolism: injury and acclimation under hypoxia and anoxia. Annu. Rev. Plant Physiol. Plant Mol. Biol. 48, 223-250.

Else, M. A., Davies, W. J., Malone, M. and Jackson, M. B. (1995). A negative hydraulic message from oxygendeficient roots of tomato plants? Plant Physiol. 109, 1017-1024.

Else, M. A., Janowiak, F., Atkinson, C. J., and Jackson, M. B. (2009). Root signals and stomatal closure in relation to photosynthesis, chlorophyll a fluorescence and adventitious rooting of flooded tomato plants. Ann. Bot. 103, 359-376.

Fernández, M. D. (2006). Changes in photosynthesis and fluorescence in response to flooding in emerged and submerged leaves of Pouteria orinocoensis. Photosynthetica 44, 32-38.

Fernández, M. D., Pieters, A., Donoso, C., Herrera, C., Tezara, W., Rengifo, E., et al. (1999). Seasonal changes in photosynthesis of trees in the flooded forest of the Mapire river. Tree Physiol. 19, 79-85.
Ferreira, C. S., Piedade, M. T. F., Franco, A. C., Carvalho Goncalves, J. F., and Junk, W. F. (2009). Adaptive strategies to tolerate prolonged flooding in seedlings of floodplain and upland populations of Himatanthus sucuuba, a Central Amazon tree. Aquat. Bot. 90, 246-252.

García-Sánchez, F., Syvertsen, J. P., Gimeno, V., Botía, P., and PerezPerez, J. G. (2007). Response to flooding and drought stress by two citrus rootstock seedlings with different water-use efficiency. Physiol. Plant. 130, 532-542.

Geigenberger, P. (2003). Response of plant metabolism to too little oxygen. Environ. Pollut. 116, 31-35.

Graffmann, K., Grosse, W., Junk, W. J., and Parolin, P. (2005). Pressurized gas transport in Amazonian floodplain trees. Biotropica 37, 609-619.

Grosse, W., Frye, J., and Lattermann, S. (1992). Root aeration in wetland trees by pressurized gas transport. Tree Physiol. 10, 285-295.

Herrera, A., Escala, M., and Rengifo, E. (2009). Leaf anatomy changes related to physiological adaptations to flooding in Amazonian tree species. Brazil. J. Plant Physiol. 21, 301-308. 
Herrera, A., Rengifo, E., and Tezara, W. (2001). "Leaf gas exchange of trees in a tropical seasonally flooded forest," in The Tree 2000, ed M. Labrecque (Montreal, QC: Isabelle Quentin), 257-262.

Herrera, A., Tezara, W., Rengifo, E., and Flores, S. (2008a). Changes with seasonal flooding in sap flow of the tropical flood-tolerant tree species, Campsiandra laurifolia. Trees 22, 551-558.

Herrera, A., Tezara, W., Marín, O., and Rengifo, E. (2008b). Stomatal and non-stomatal limitations of photosynthesis in trees of a tropical seasonally flooded forest. Physiol. Plant. 134, 41-48.

Islam, M. A., and Macdonald, S. E. (2004). Ecophysiological adaptations of black spruce (Picea mariana) and tamarack (Larix laricina) seedlings to flood. Trees 18, 35-42.

Izquierdo, L. (1988). Efecto de la Inundación Sobre la Actividad Metabólica en Raíces de una Especie Arbórea, Acosmium nitens (Vog.) Yakoul (Papilonaceae) de áreas Estacionalmente Inundables. Licenciado thesis, Universidad Central de Venezuela, Caracas.

Jackson, M. (1997). Hormones from roots as signals for the shoots of stressed plants. Trends Plant Sci. 2, 22-28.

Jackson, M. B., and Colmer, T. D. (2005). Response and adaptation by plants to flooding stress. Ann. Bot. 96, 501-505.

James, E. K., and Crawford, R. M. M. (1998). Effect of oxygen availability on nitrogen fixation by two Lotus species under flooded conditions. J. Exp. Bot. 49, 599-609.

Joly, C. A., and Crawford, R. M. M. (1982). Variation in tolerance and metabolic responses to flooding in some tropical trees. J. Exp. Bot. 33, 799-809.

Konnerup, D., Sorrell, B. K., and Brix, H. (2011). Do tropical wetland plants possess convective gas flow mechanisms? New Phytol. 190, 379-386.

Kozlowski, T. T. (1984). Plant responses to flooding of soil. BioScience 34, 162-167.

Kozlowski, T. T. (1997). Responses of woody plants to flooding and salinity. Tree Physiol. Monogr. 1, 1-29.

Kreuzwieser, J., Furniss, S., and Rennenberg, H. (2002). Impact of waterlogging on the $\mathrm{N}$-metabolism of flood tolerant and non-tolerant tree species. Plant Cell Environ. 25, 1039-1049.

Kreuzwieser, J., Papadopoulou, E., and Rennenberg, H. (2004). Interaction of flooding with carbon metabolism of forest trees. Plant Biol. 6, 299-306.

Lopez, O. R., and Kursar, T. A. (1999). Flood tolerance of four tropical tree species. Tree Physiol. 19, 925-932.

McElrone, A. J., Bichler, J., Pockman, W. T., Addington, R. N., Linder, C. R., and Jackson, R. B. (2007) Aquaporin-mediated changes in hydraulic conductivity of deep tree roots accessed via caves. Plant Cell Environ. 30, 1411-1421.

Melack, J. M., Hess, L. L., Gastil, M., Forsberg, B. R., Hamilton, S K. I., Lima, B. T., et al. (2004). Regionalization of methane emissions in the Amazon Basin with microwave remote sensing. Glob. Change Biol. 10, 530-544.

Mielke, M. S., de Almeida, A.-A. F. Gomes, F. P., Aguilar, M. A. G. and Mangabeira, P. A. O. (2003). Leaf gas exchange, chlorophyll fluorescence and growth responses of Genipa americana seedlings to soil flooding. Environ. Exp. Bot. 50, 221-231.

Mommer, L., Pons, T., Wolters-Arts, M., Venema, J., and Visser, E. (2005). Submergence-induced morphological, anatomical, and biochemical responses in a terrestrial species affect gas diffusion resistance and photosynthetic performance. Plant Physiol. 139, 497-508.

Otte, M. L. (2001). What is stress to a wetland plant? Environ. Exp. Bot. 46, 195-202.

Parolin, P. (2000). Phenology and $\mathrm{CO}_{2}$-assimilation of trees in Central Amazonian floodplains. J. Trop. Ecol. 16, 465-473.

Parolin, P. (2001). Morphological and physiological adjustments to waterlogging and drought in seedlings of Amazonian floodplain trees. Oecologia 128, 326-335.

Parolin, P., Armbrüster, N., and Junk, W. J. (2002). Seasonal changes of leaf nitrogen content in trees of amazonian floodplains. Acta Amazon. 32, 123-132.

Parolin, P., Armbrüster, N., and Junk, W. J. (2006). Two Amazonian flooplain trees react differently to periodical flooding. Trop. Ecol. 47, 243-250.

Parolin, P., and Wittmann, F. (2010). Struggle in the flood: tree responses to flooding stress in four tropical floodplain systems. AoB Plants 2010:plq003. doi: 10.1093/aobpla/plq003

Perata, P., Armstrong, W., and Voesenek, L. A. C. J. (2011). Plants and flooding stress. New Phytol. 190, 269-273.

Pezeshki, S. R. (1987). Gas exchange response of tupelo-gum (Nissa aquatica L.) to flooding and salinity. Photosynthetica 21, 489-493.

Pezeshki, S. R. (1993). Differences in patterns of photosynthetic responses to hypoxia in floodtolerant and flood-sensitive tree species. Photosyntetica 28, 423-430.

Prance, G. T. (1979). Notes on the vegetation of Amazonia. III. Terminology of Amazonian forest types subjected to inundation. Brittonia 31, 26-38.

Rengifo, E., Herrera, A., Tezara, W. and Flores, S. (2006). Efecto de la Inundación y la Sequía Sobre la Conductancia Estomática, el Contenido ABA Xilemático y Foliar y el Estado Hídrico de dos Especies Arbóreas Tropicales Tolerantes a la Inundación. Santo Domingo: IX Congreso Latinoamericano de Botánica.

Rengifo, E., Tezara, W., and Herrera, A. (2005). Water relations, chlorophyll a fluorescence and carbohydrate contents in trees of a tropical forest in response to flood. Photosynthetica 43, 203-210.

Roças, G., and Scarano, F. R. (2001). Leaf anatomical variation in Alchornea triplinervia (Spreng) Müll. Arg. (Euphorbiaceae) under distinct light and soil water regimes. Trop. Ecol. 47, 243-250.

Rosales, J. (1988). Análisis FlorísticoEstructural y Algunas Relaciones Ecológicas en un Bosque Inundable en la Boca del río Mapire, Edo. Anzoátegui. M.Sc. thesis, Instituto Venezolano de Investigaciones Científicas, Caracas, 233.

Roth, I., and Lindorf, H. (1991). Leaf structure of species of Pachira indigenous of Venezuela from different habitats. Bot. Jahrb. Syst. 113 203-219.

Ruiz-Sánchez, M. C., Domingo, R., Morales, D., and Torrecillas, A. (1996). Water relations of Fino lemon plants on two rootstocks under flooded conditions. Plant Sci. 120 119-125.

Snyder, K. A., James, J. J., Richards, J. H., and Donovan, L. A. (2008) Does hydraulic lift or nighttime transpiration facilitate nitrogen acquisition? Plant Soil 306, 159-166.

Sun, O. J., Sweet, G. B., Whitehead, D., and Buchan, G. D. (1995) Physiological responses to water stress and waterlogging in Nothofagus species. Tree Physiol. $15,629-638$.

Tournaire-Roux, C., Sutka, M., Javot, H., Gout, E., Gerbeau, P., Luu, D.-T., et al. (2003). Cytosolic pH regulates root water transport during anoxic stress through gating of aquaporins. Nature 425, 393-397.

Vegas-Vilarrúbia, T., and Herrera, R. (1993a). Seasonal alternation of lentic/lotic conditions in the Mapire system, a tropical floodplain lake in Venezuela. Hydrobiologia 262, 43-55.

Vegas-Vilarrúbia, T., and Herrera, R. (1993b). Effects of periodic flooding on the water chemistry and primary production of the Mapire system (Venezuela). Hydrobiologia 262, 31-42.

Waldhoff, D. (2009). Leaf structure in trees of Central Amazonian floodplain forests (Brazil). Environ. Exp. Bot. 66, 135-142.

Waldhoff, D., and Furch, B. (2002) Leaf morphology and anatomy in eleven tree species from Central Amazonian floodplains (Brazil). Amazoniana 17, 79-94.

Waldhoff, D., Furch, B., and Junk, W. (2002). Fluorescence parameters, chlorophyll concentration, and anatomical features as indicators for flood adaptation of an abundant tree species in Central Amazonia: Symmeria paniculata. Environ. Exp. Bot. 48, 225-235.

Wang, W., Yan, Z., You, S., Zhang, Y., Chen, L., and Lin, G. (2011) Mangroves: obligate or facultative halophytes? A review. Trees 25, 953-963.

Conflict of Interest Statement: The author declares that the research was conducted in the absence of any commercial or financial relationships that could be construed as a potential conflict of interest.

Received: 26 January 2013; accepted: 08 April 2013; published online: 01 May 2013.

Citation: Herrera A (2013) Responses to flooding of plant water relations and leaf gas exchange in tropical tolerant trees of a black-water wetland. Front. Plant Sci. 4:106. doi: 10.3389/fpls.2013.00106

This article was submitted to Frontiers in Plant Physiology, a specialty of Frontiers in Plant Science.

Copyright (c) 2013 Herrera. This is an open-access article distributed under the terms of the Creative Commons Attribution License, which permits use, distribution and reproduction in other forums, provided the original authors and source are credited and subject to any copyright notices concerning any third-party graphics etc. 